\title{
Perancangan Sistem Informasi Lembaga Keuangan Mikro Agrobisnis (LKMA) Prima Agung Kanagarian Sungai Duo Kecamatan Sitiung Kabupaten Dharmasraya
}

\author{
Ilfa Stephane ${ }^{1}$, Heru Saputra² \\ STMIK Indonesia Padang, JI. Khatib Sulaiman Dalam, Sumatra Utara, Indonesia \\ ${ }^{1}$ e-mail: ilfastephane@gmail.com \\ 2h3ru.saputra@gmail.com
}

\begin{abstract}
Abstrak
Lembaga Keuangan Mikro Agrobisnis (LKMA) Prima Agung Kenagarian Sungai Duo Kecamatan Sitiung Kabupaten Dharmasraya merupakan salah satu bentuk koperasi yang bergerak pada bidang usaha simpan pinjam. Dalam pengelolaannya, sistem konvensional berupa buku besar masih digunakan. Cara ini kurang efektif untuk transaksi simpan pinjam dalam jumlah banyak karena dibutuhkan ketelitian dalam pengolahan data akuntansi seperti melakukan pengulangan penulisan yang dapat mengakibatkan pemborosan waktu pengerjaan. Dengan adanya permasalahan tersebut, LKMA Prima Agung perlu menggunakan suatu aplikasi simpan pinjam yang dapat membantu dalam proses pengolahan data. Adapun metode penelitian yang digunakan dalam penelitian ini yaitu identifikasi masalah, studi literatur, pengumpulan dan penetapan data, perancangan sistem, analisis, desain dan implementasi sistem. Hasil penelitian ini diharapkan dapat menjadi solusi alternatif khususnya bagi LKMA Prima Agung dalam menyelesaikan berbagai proses transaksi secara efektif dan efisien.
\end{abstract}

Kata kunci: LKMA Prima Agung, Sistem Informasi.

\begin{abstract}
Microfinance Institutions Agribusiness (LKMA) Prima Agung Kenagarian Sungai Duo Kecamatan Sitiung Kabupaten Dharmasraya is one form of cooperatives engaged in the field of micro-credit. In management, conventional systems are still used in the form of a book. This method is less effective for savings and loan transactions in large quantities because it required precision in processing accounting data such as repetition of writing that can lead to wastage of working time. With the existence of these problems, LKMA Prima Agung needs to use a savings and loan applications that can assist in data processing. The research method used in this study is the identification of the problem, literature, and the establishment of data collection, system design, analysis, design and implementation of the system. The results of this study are expected to be an alternative solution, especially for LKMA Prima Agung in completing various transaction processes effectively and efficiently.
\end{abstract}

Keywords: LKMA Prima Agung, Information System.

\section{Pendahuluan}

Lembaga Keuangan Mikro Agrobisnis (LKMA) Prima Agung merupakan lembaga koperasi yang bergerak pada bidang jasa keuangan, yang melayani anggota khususnya dalam bidang pelayanan simpan pinjam. LKMA Prima Agung berlokasi di Kanagarian Sungai Duo Kecamatan Sitiung Kabupaten Dharmasraya yang didirikan oleh sekelompok masyarakat yang ingin memberikan kemudahan bagi masyarakat kecil agar dapat memenuhi kebutuhan sehari-hari. Koperasi LKMA Prima Agung mempuyai produk berupa pinjaman kredit dimana pinjaman tersebut diangsur setiap bulannya oleh masyarakat kepada pihak LKMA Prima Agung, selain itu 
masyarakat juga dapat melakukan penyimpanan uang setiap seminggu sekali. Dalam hal ini diharapkan masyarakat dapat terbantu dengan adanya program atau aplikasi yang disediakan oleh LKMA Prima Agung. Dengan jumlah anggota 210.691 orang pada akhir tahun 2013 pengelolaan keuangan dan keanggotaan pada koperasi ini masih menggunakan sistem konvensional yaitu menggunakan buku besar dan aplikasi umum yang ada di kantor. Dengan jumlah anggota yang ada di LKMA Prima Agung cara ini kurang efektif karena transaksi simpan pinjam yang terjadi semakin tinggi sehingga perhitungan juga semakin banyak. Dalam pengolahan akuntansi juga membutuhkan ketelitian karena banyak pengulangan penulisan yang membutuhkan ketelitian dan pemborosan waku pengerjaan.

Pada penelitian yang dilakukan oleh [1] yang berjudul Sistem Informasi Simpan Pinjam pada koperasi Wanita Putri Harapan Desa Jatigunung Kecamatan Tulakan menunjukkan bahwa penggunaan sistem informasi dapat memberikan kemudahan, kecepatan dan keakuratan dalam pengolahan data dan pembuatan laporan. Begitu pula dengan penelitian lain yang ditulis oleh [2] yang berjudul Rancangan Sistem Informasi Koperasi Simpan Pinjam Guru dan Pegawai pada Koperasi SMK Manggala Tangerang, mengungkapkan bahwa dengan adanya sistem informasi dapat membantu pengolahan data sehingga dapat mengurangi kesalahan user.

Berdasarkan paparan di atas, maka LKMA Prima Agung perlu menggunakan sistem informasi yang dapat membantu dalam proses pengolahan data simpan pinjam dan data keanggotaan secara lebih cepat, mudah, aman dan menghasilkan data akurat.

\section{Metodologi Penelitian}

Tahap pertama yang dilakukan pada penelitian ini adalah tahap perencanaan. Pada tahap ini penulis melakukan identifikasi masalah, studi literatur terkait penelitian, pengumpulan dan penetapan data yang digunakan untuk membangun sistem informasi LKMA Prima Agung Kanagarian Sungai Duo Kecamatan Sitiung Kabupaten Dharmasraya. Tahap selanjutnya adalah melakukan perancangan sistem menggunakan System Development Life Cycle (SDLC) yang terdiri dari analisis, desain dan implementasi.

\section{Kajian Pustaka}

\subsection{Pengertian Perancangan}

Perancangan adalah langkah awal dalam membuat suatu sistem. Menurut [3], perancangan adalah proses pengembangan spesifikasi baru berdasarkan rekomendasi hasil analisis sistem. Sedangkan menurut [4], tahapan perancangan memiliki tujuan untuk mendesain sistem baru yang dapat menyelesaikan masalah-masalah yang dihadapi perusahaan yang diperoleh dari pemilihan alternatif sistem yang terbaik. Dan menurut [5], perancangan adalah proses pengembangan spesifikasi sistem baru berdasarkan hasil rekomendasi analisis sistem.

\subsection{Pengertian Sistem}

Sistem dapat didefinisikan sebagai suatu jaringan kerja dari prosedur-prosedur yang saling berhubungan, berkumpul bersama-sama untuk melakukan suatu kegiatan atau untuk menyelesaikan suatu sasaran tertentu [6].

Menurut [7] sistem adalah sekelompok unsur yang erat hubungannya satu dengan yang lain, yang berfungsi bersama-sama untuk mencapai tujuan tertentu. Sedangkan menurut [8], sistem adalah sebuah tatanan (keterpaduan) yang terdiri atas sejumlah komponen fungsional dengan satuan fungsi dan tugas khusus yang saling berhubungan dan secara bersama-sama bertujuan untuk memenuhi suatu proses tertentu.

Dengan demikian, secara umum sistem dapat didefinisikan sebagai kumpulan hal atau elemen yang saling bekerja sama atau yang dihubungkan dengan cara-cara tertentu sehingga membentuk satu kesatuan untuk melaksanakan suatu fungsi guna mencapai suatu tujuan [9]. 


\subsection{Pengertian Informasi}

Menurut [10] informasi adalah hasil pengolahan data sehingga menjadi bentuk yang penting bagi penerimanya dan mempunyai kegunaan sebagai dasar dalam pengambilan keputusan yang dapat dirasakan akibatnya secara langsung saat itu atau secara tidak langsung pada saat mendatang.

Informasi adalah data yang telah diproses kedalam suatu bentuk yang mempunyai arti bagi si penerima dan mempunyai nilai nyata dan terasa bagi keputusan saat itu atau keputusan mendatang [7].

\subsection{Sistem Informasi}

Sistem informasi adalah suatu sistem di dalam suatu organisasi yang mempertemukan kebutuhan pengolahan transaksi harian yang mendukung fungsi operasi organisasi yang bersifat manajerial dengan kegiatan strategi dari suatu organisasi untuk dapat menyediakan laporan-laporan yang diperlukan oleh pihak luar tertentu [7].

Menurut [11], sistem informasi adalah kombinasi antara prosedur kerja, informasi, orang, dan teknologi informasi yang diorganisasikan untuk mencapai tujuan dalam sebuah organisasi. Sedangkan menurut [3], sistem informasi merupakan kumpulan dari perangkat keras dan perangkat lunak komputer serta perangkat manusia yang akan mengolah data menggunakan perangkat keras memegang peranan yang penting dalam sistem informasi. Data yang akan dimasukkan dalam sebuah sistem informasi dapat berupa formulir-formulir, prosedur-prosedur dan bentuk data lainnya.

\subsection{Koperasi}

Menurut Pasal 1 Ayat 1 Undang-undang No. 25 / Tahun 1992 tentang Koperasi (yang selanjutnya disebut UU Perkop) koperasi adalah badan usaha yang beranggotakan orang seorang atau badan hukum koperasi dengan melandaskan kegiatannya berdasar prinsip koperasi sekaligus sebagai gerakan ekonomi rakyat yang berdasar atas asas kekeluargaan [12].

\section{Hasil dan Pembahasan}

\subsection{Analisis Sistem Baru}

Analisis sistem baru yang diusulkan secara garis besar memiliki tujuan untuk menghasilkan suatu bentuk rancangan baru yang berguna mengatasi kelemahan dan masalah yang dihadapi dalam pengolahan data simpan pinjam dan data keanggotaan LKMA Prima Agung.

Analisis dan perancangan sistem ini diharapkan bisa digunakan untuk mendukung kegiatan pengolahan data, penyimpanan data, dan pembuatan laporan yang ditujukan kepada manager maupun bagian lain yang berkepentingan serta bisa membuat data arsip sendiri.

\subsection{Aliran Sistem Baru}

Langkah awal dari proses perencanaan sistem informasi yang baru adalah melakukan identifikasi secara lengkap terhadap tujuan, sasaran, dan hambatan dalam LKMA Prima Agung. Perancangan sistim ini bertujuan untuk memberikan kemudahan atau kedekatan antara informasi yang tersedia dengan penggunanya. Dengan terbentuknya sistem informasi ini diharapkan bisa mendukung kegiatan administrasi dari manajemen sehingga dapat memberikan informasi yang berkualitas bagi pengguna.

Penyajian sistem informasi yang baru akan langsung dilakukan oleh sistem. Berbeda dengan sistem informasi yang lama dimana proses pembuatan dan pengolahan data hanya dapat diketahui pihak-pihak yang langsung terlibat dalam proses tersebut. Berikut ini adalah gambar aliran sistem informasi yang baru: 


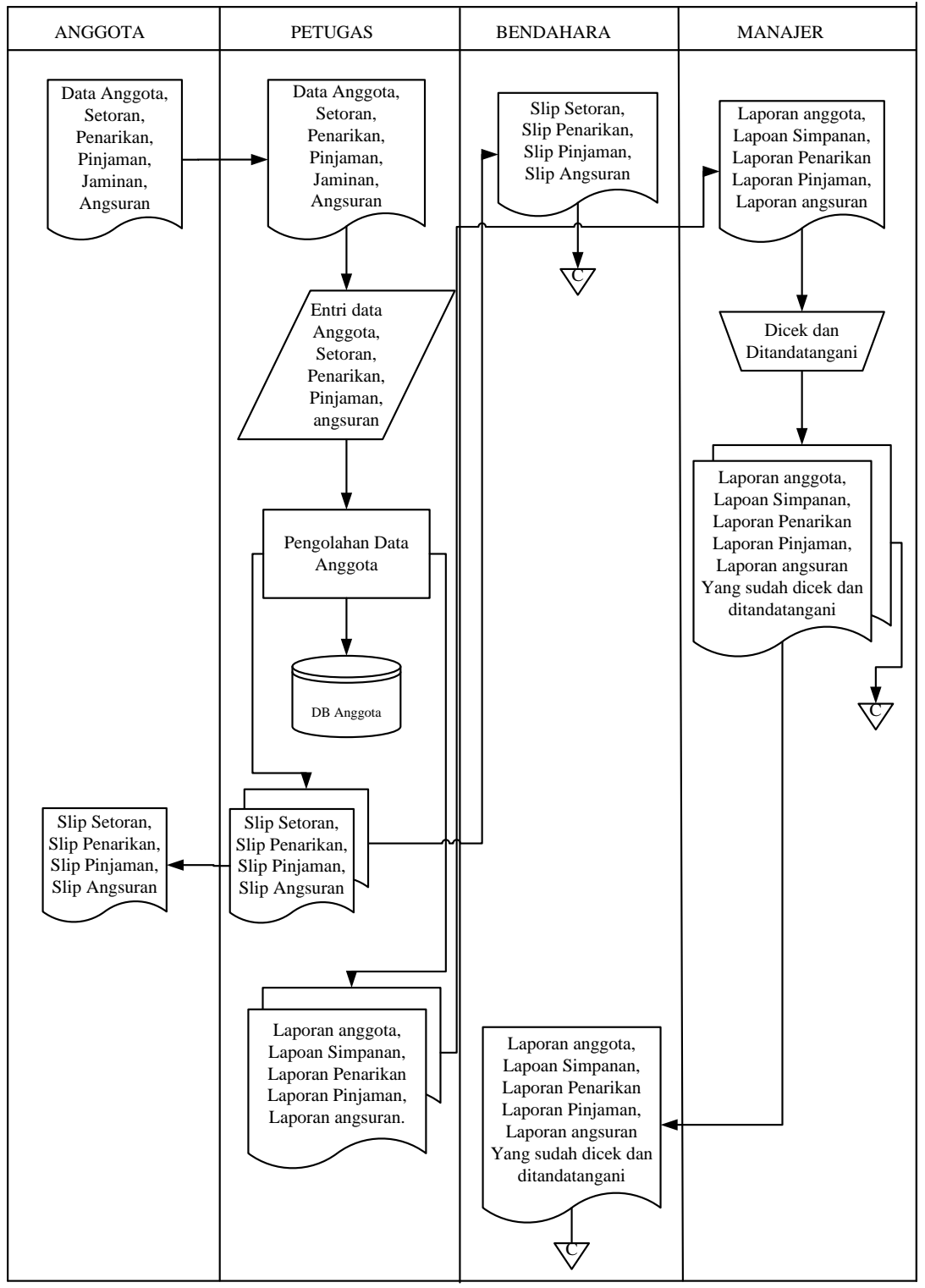

Gambar 1. Analisis Sistem Baru

Keterangan gambar:

Sistem terdiri dari 4 entitas yaitu anggota, petugas, bendahara, dan manajer. Masing-masing entitas memiliki peran dalam proses kerja sistem informasi ini yaitu:

a. Anggota sebagai entitas berperan memberikan data lengkap yang akan diinput ke dalam sistem. Dalam aliran sistem informasi ini anggota mempunyai 6 data yang akan diinput yaitu data anggota, setoran, penarikan, pinjaman, jaminan, dan angsuran.

b. Petugas sebagai entitas berperan dalam penginputan dan pemrosesan data dari anggota yang menghasilkan slip setoran, slip penarikan, slip pinjaman, slip angsuran, laporan keanggotaan, laporan simpanan, laporan pinjaman, dan laporan angsuran. Semua slip akan dirangkap menjadi dua kemudian satu rangkap akan diserahkan kepada anggota dan satu rangkap lainnya akan dijadikan arsip oleh petugas. Sedangkan laporan akan diteruskan kepada bendahara. Data-data yang sudah diinput akan tersimpan dalam database.

c. Bendahara sebagai entitas berperan dalam penerimaan slip dan laporan data-data yang telah diolah oleh petugas. 
d. Manajer sebagai entitas dapat melihat hasil pengolahan data berupa laporan yang sudah tersimpan dalam database dengan mudah dan akurat.

\subsection{Hierarchy Input Process Output (HIPO)}

Hierarchy Input Process Output merupakan alat perancangan untuk mendokumentasikan program dalam pengembangan sistem. Berikut adalah HIPO Sistem Informasi LKMA Prima Agung.

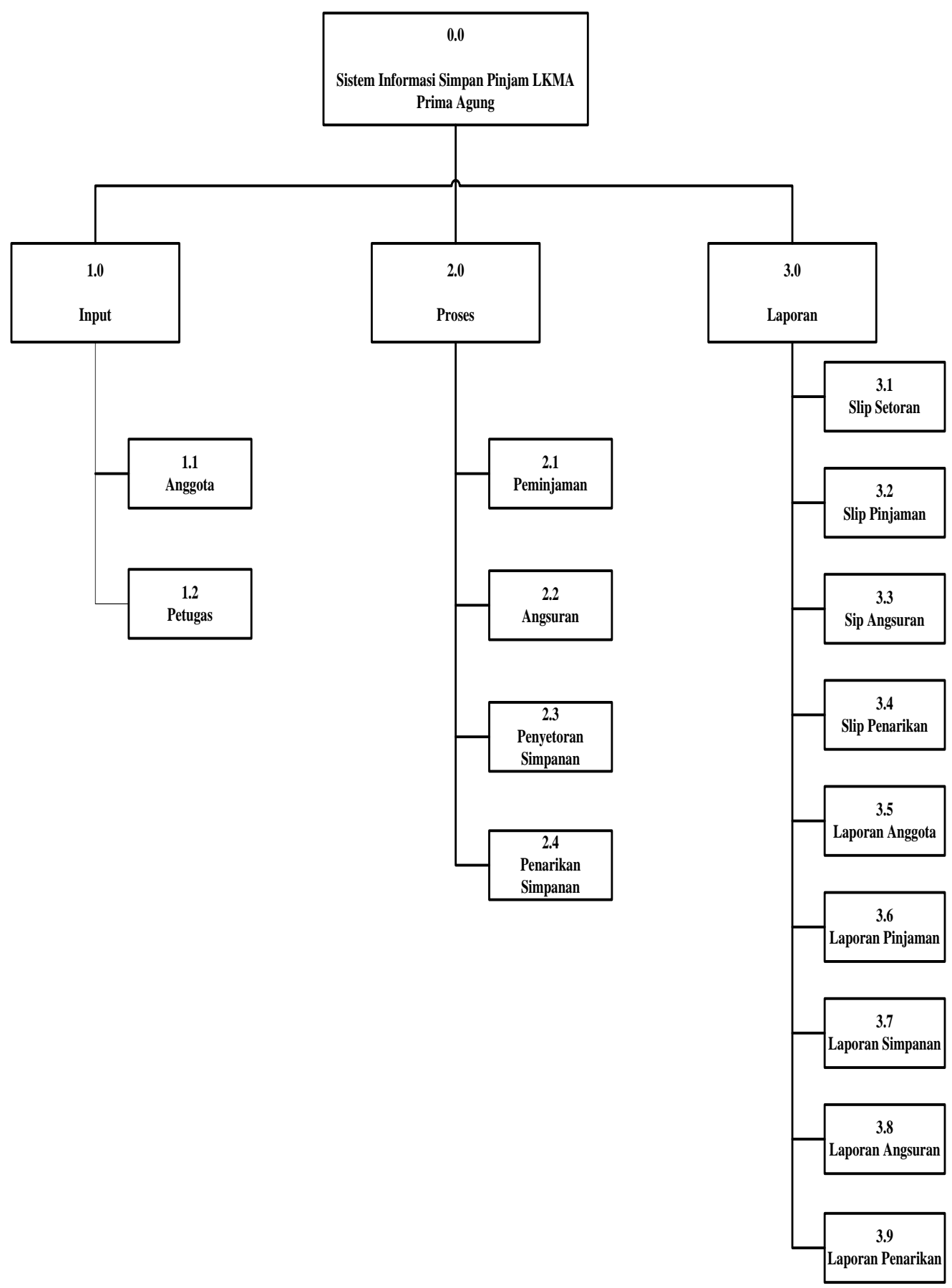

Gambar 2. HIPO Sistem Informasi LKMA Prima Agung 


\subsection{Context Diagram}

Context Diagram merupakan alat bantu perancangan yang memperlihatkan sistem secara umum dan subsistem yang terlibat dalam sistem secara keseluruhan. Pada bagian Context Diagram ini, perancangan sistem informasi LKMA Prima Agung terdiri dari empat entitas yang saling berinteraksi satu dengan yang lainnya. Berikut digambarkan bentuk Context Diagram yang dirancang pada analisa dan perancangan Sistem Informasi LKMA Prima Agung.

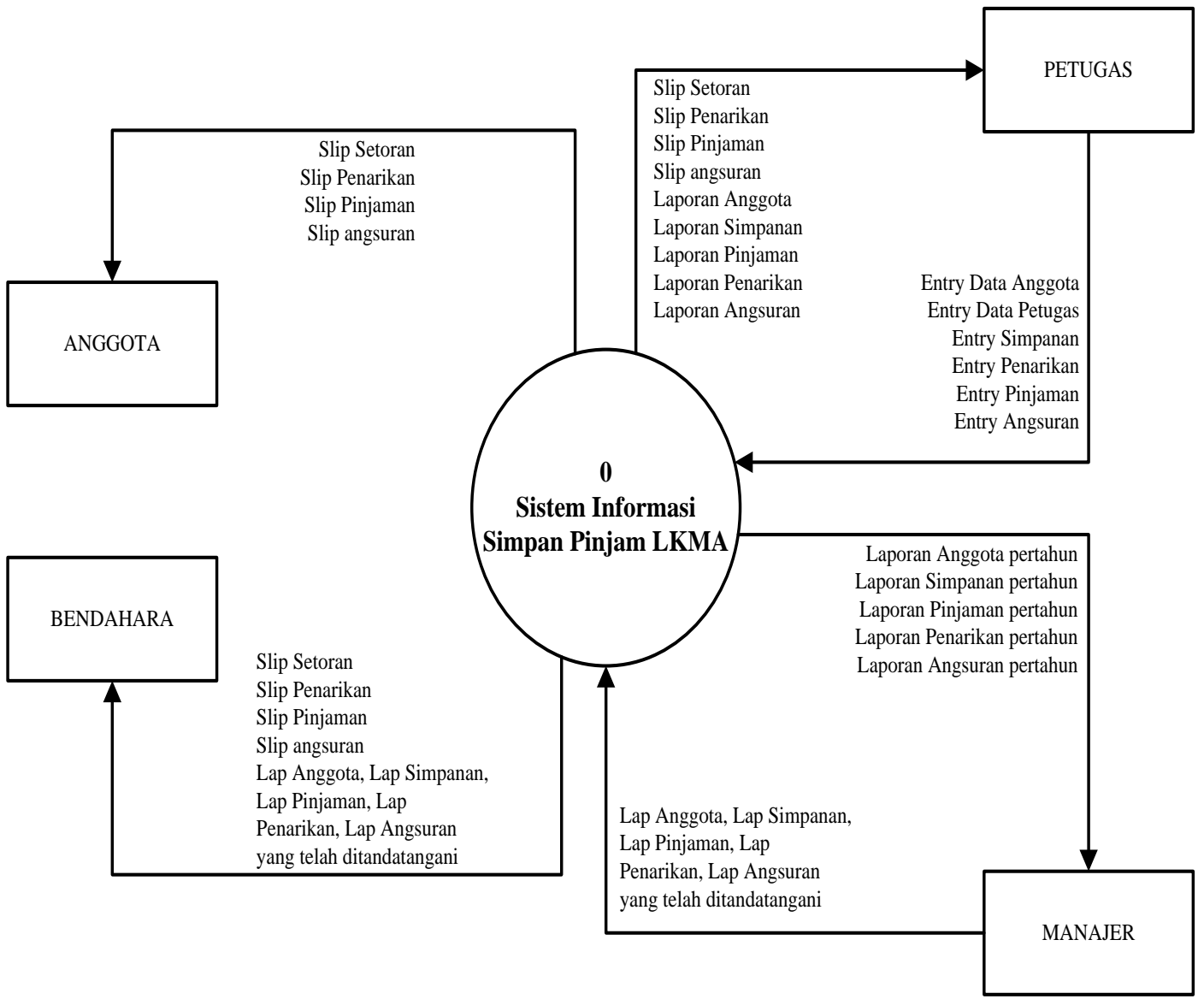

Gambar 3. Context Diagram Sistem Informasi LKMA Prima Agung

Dari Context Diagram di atas diketahui bahwa:

a. Entitas yang memberikan masukan ke dalam sistem adalah Petugas berupa data anggota, data petugas, setoran, penarikan, pinjaman, jaminan, dan angsuran.

b. Entitas yang menerima keluaran sistem berupa slip setoran,slip penarikan slip pinjaman, dan slip angsuran adalah Anggota dan Bendahara. Sedangkan keluaran berupa laporan anggota, laporan simpanan, laporan pinjaman, laporan penarikan, dan laporan angsuran adalah Bendahara dan Manajer.

\subsection{Data Flow Diagram (DFD)}

Data Flow Diagram adalah diagram yang menguraikan proses pada Context Diagram dalam bentuk yang lebih detail menyangkut masalah penyerahan laporan. Berikut gambaran DFD untuk Sistem Informasi LKMA Prima Agung yang baru. 


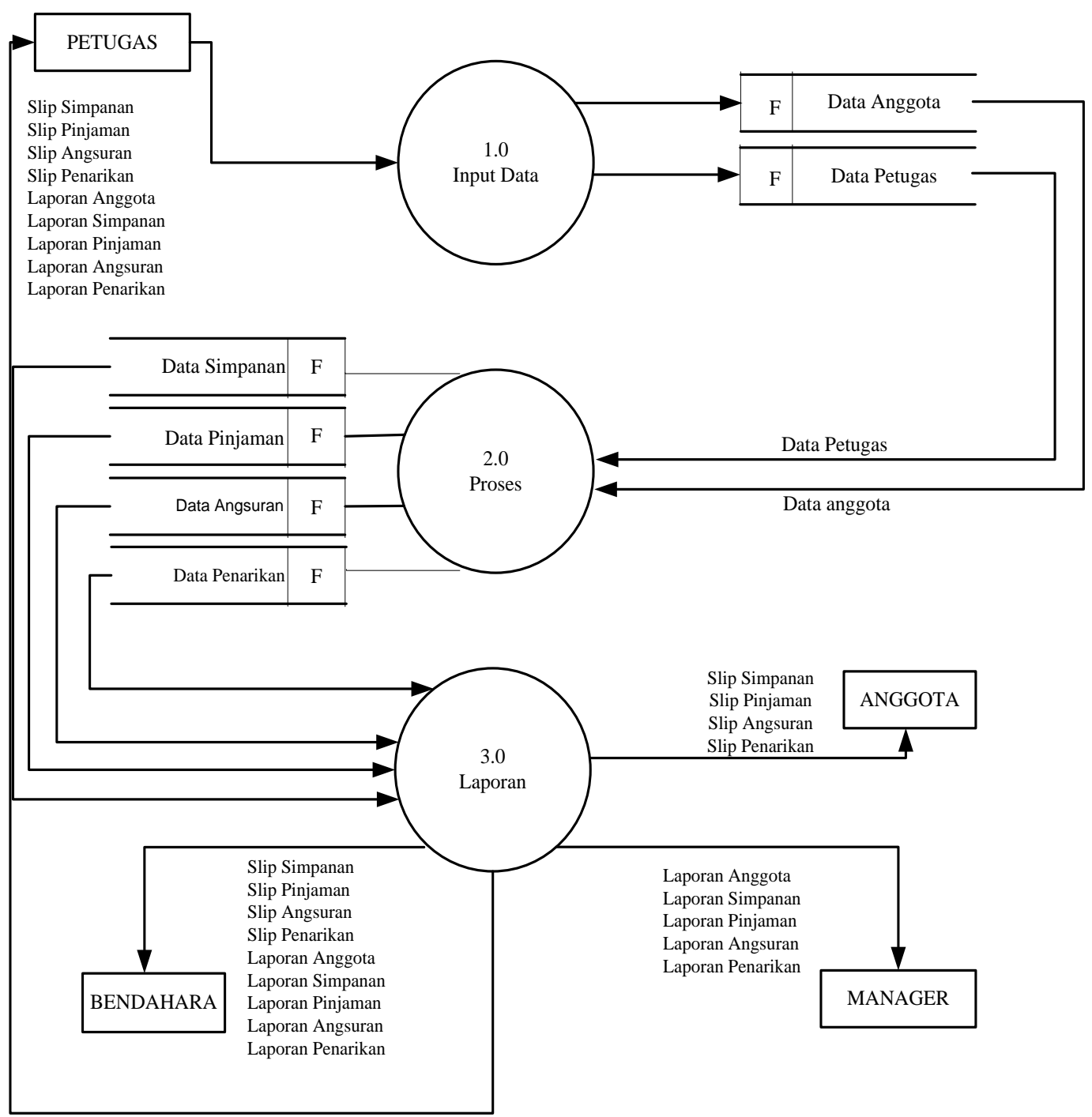

Gambar 4. Data Flow Diagram Sistem Informasi LKMA Prima Agung

\subsection{Entity Relationship Diagram (ERD)}

Adapun gambar Entity Relationship Diagram adalah sebagai berikut: 


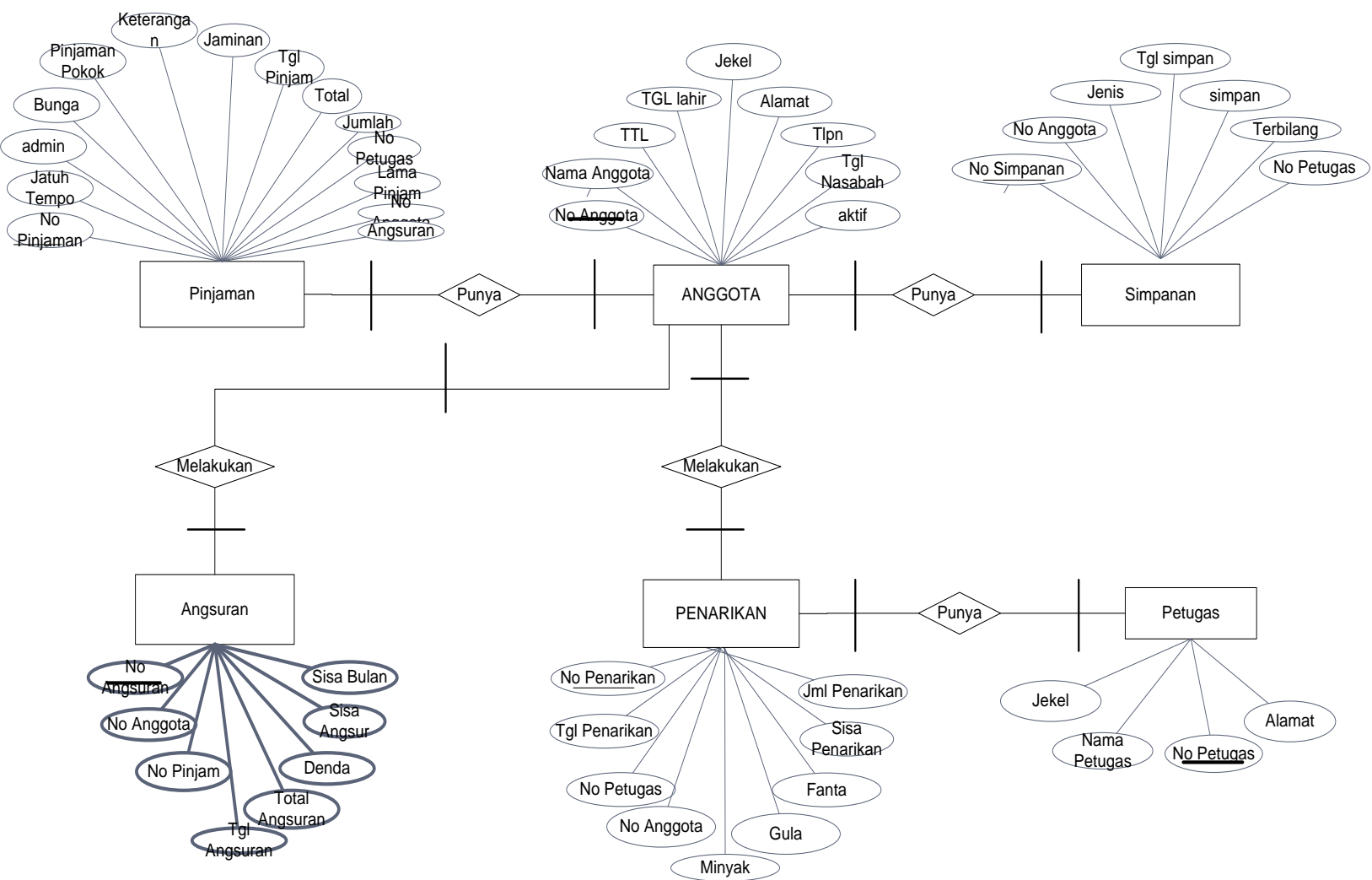

Gambar 5. ERD Sstem Informasi LKMA Prima Agung

\subsection{Rancangan Input}

Rancangan formulir Input dibuat untuk memasukkan data-data ke dalam database. Adapun rancangan input dapat dilihat dari gambar berikut:

a. Form Input Data Petugas

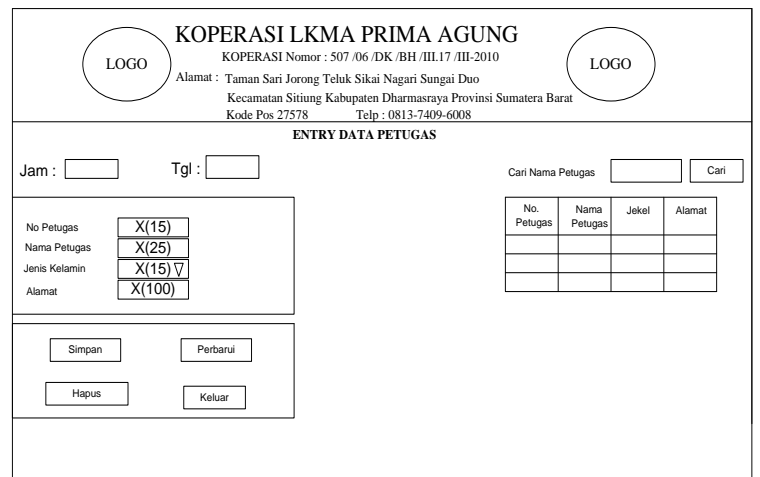

Gambar 6. Rancangan Input Data Petugas b. Form Input Data Anggota

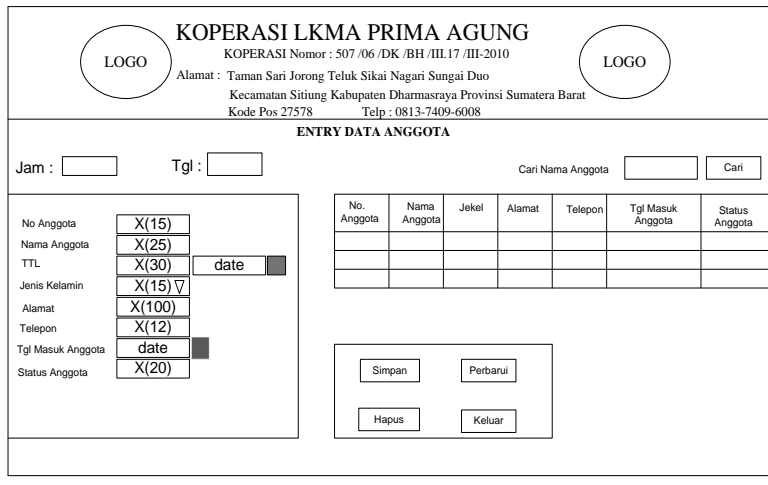

Gambar 7. Rancangan Input Data Anggota 


\subsection{Rancangan Proses}

Rancangan proses merupakan tampilan untuk melakukan proses suatu kegiatan yang sesuai dengan tujuan kegiatan.

\section{a. Form Transaksi Simpanan}

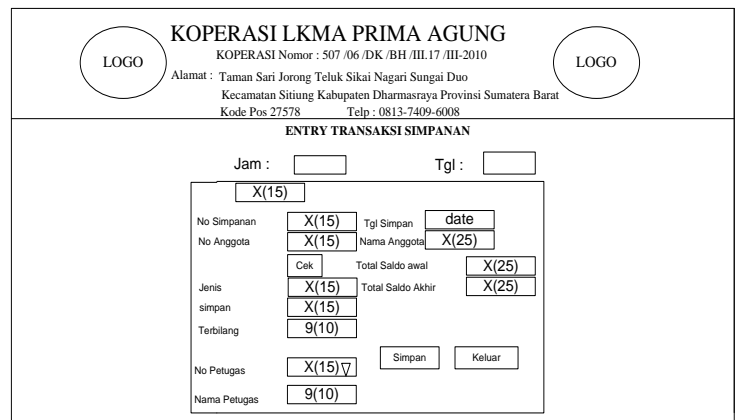

Gambar 8. Transaksi Simpanan

c. Form Angsuran

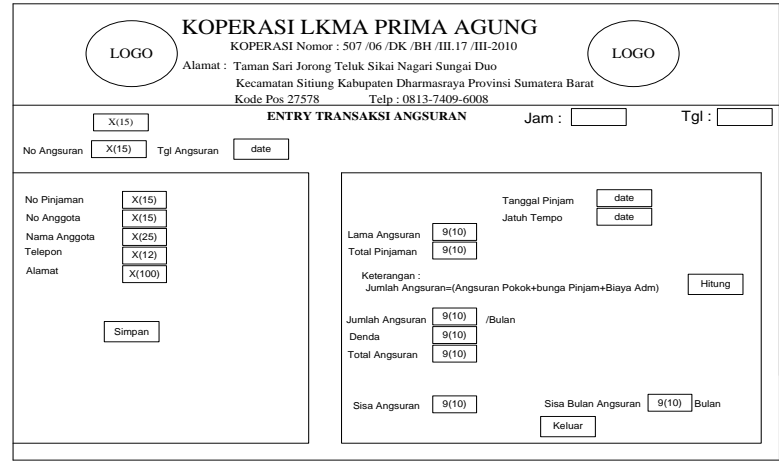

Gambar 10. Angsuran b. Form Transaksi Peminjaman

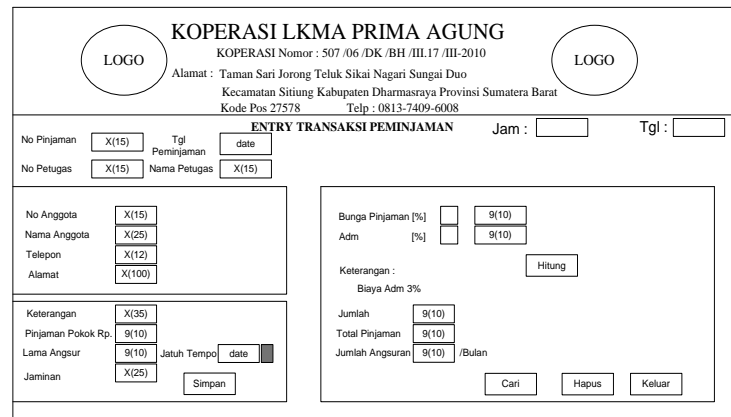

Gambar 9. Transaksi Peminjaman

d. Form Penarikan

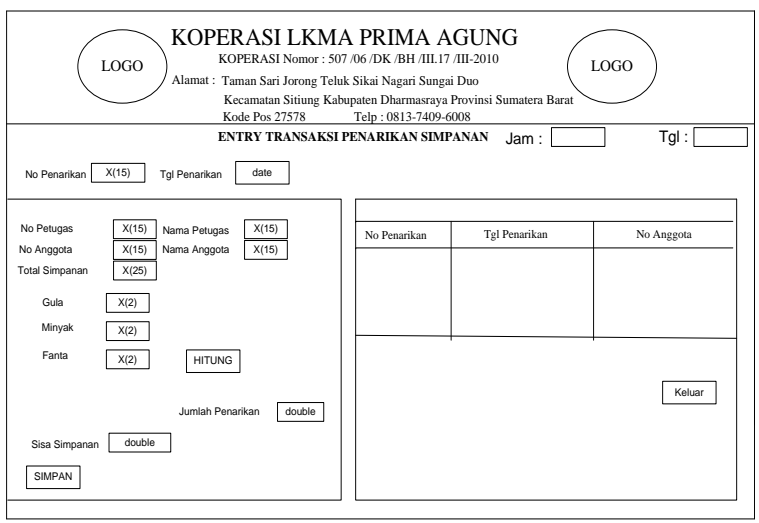

Gambar 11. Penarikan

\subsection{Rancangan Output}

Rancangan output merupakan tampilan atau keluaran dari hasil suatu kegiatan yang diinginkan.

a. Rancangan Laporan Anggota

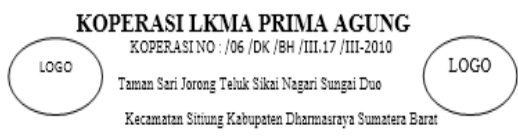

Kode Pos 22578 - Telig :0813-7400-6008

LAPORAN ANGGOTA LKMA PRIMA AGUNG PERTAHUN

\begin{tabular}{|c|c|c|c|c|c|c|c|}
\hline \multicolumn{8}{|c|}{ Tahun : 9999} \\
\hline No & No.Adggota & Nama Anggovat & Jenis Kellamin & . Ilamat & Telepor: & 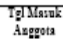 & States Augpots \\
\hline $9(10)$ & $\bar{X}[1]$ & $X(2)$ & $X(15)$ & $X(100)$ & $9(12)$ & & $x(0)$ \\
\hline$Z$ & & & & & & $99-99-99999$ & \\
\hline $9(10)$ & $\mathrm{x}(15)$ & $\mathrm{x}(2.5)$ & $\mathrm{x}(15)$ & $\mathrm{x}(100)$ & $9(12)$ & & $x(20)$ \\
\hline
\end{tabular}

a/n Pengurus KOPERASI LKMA PRIMA AGUNG

Ketua Umum

Sekretaris

Gambar 12. Laporan Anggota

b. Rancangan Laporan Simpanan

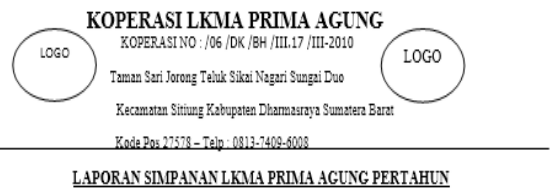

LAPORAN SIMPANAN LKMG PRIMA AGUNG PERTAHUN

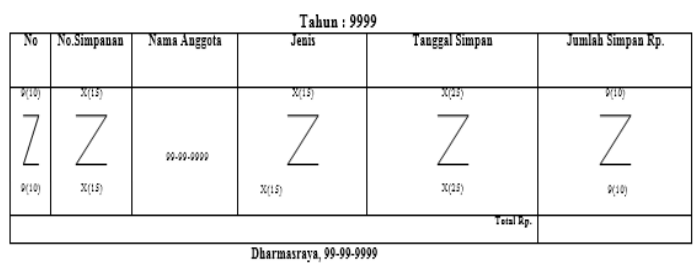

à Peagurus KOPERASI LKMA PRIMA AGUNG

Ketua Umum

Selretaris

Bendahars

Gambar 13. Rancangan Laporan Simpanan 
c. Rancangan Laporan Pinjaman

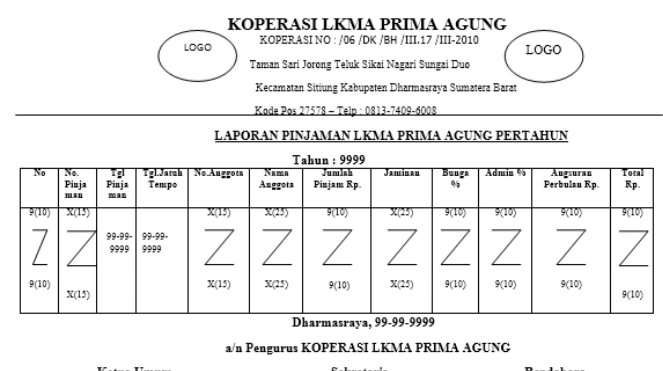

Gambar 14. Rancangan Laporan Pinjaman

e. Rancangan Laporan Angsuran

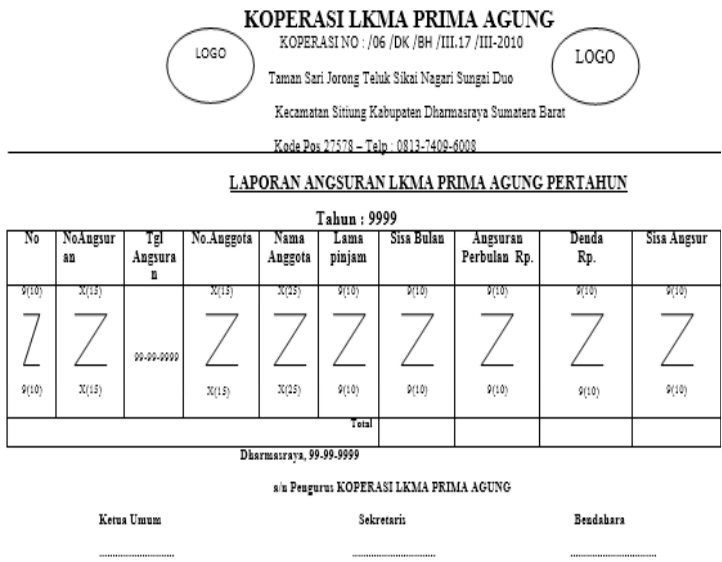

Gambar 16. Rancangan Laporan Angsuran

g. Rancangan Slip Penarikan

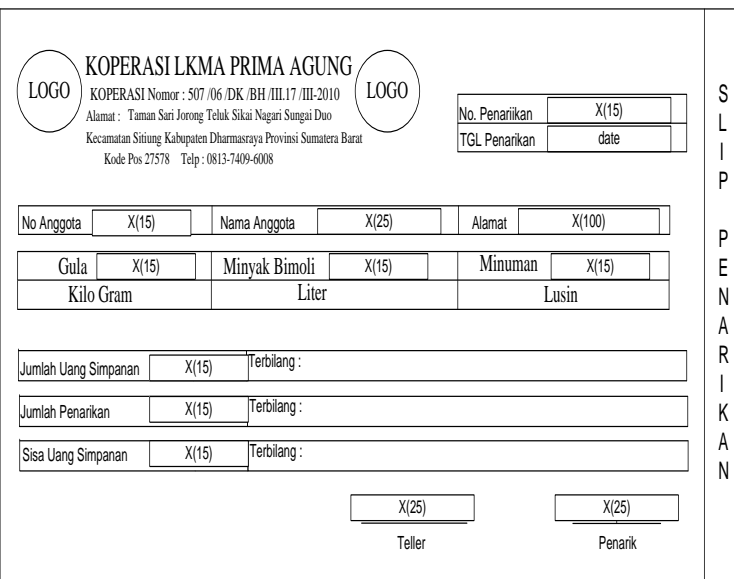

Gambar 18. Rancangan Slip Penarikan d. Rancangan Laporan Penarikan

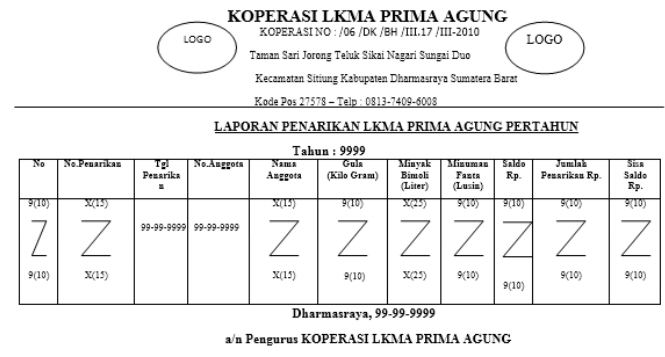

Gambar 15. Rancangan Laporan Penarikan

f. Rancangan Slip Setoran

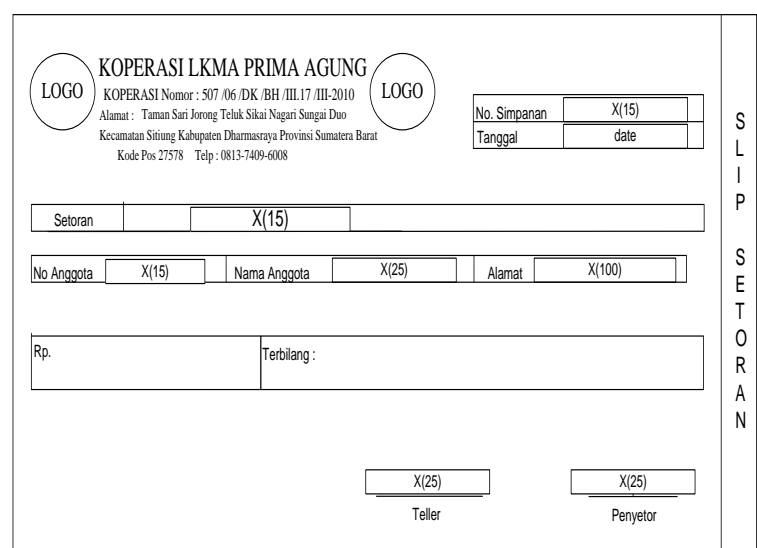

Gambar 17. Rancangan Slip Setoran

h. Rancangan Slip Pinjaman

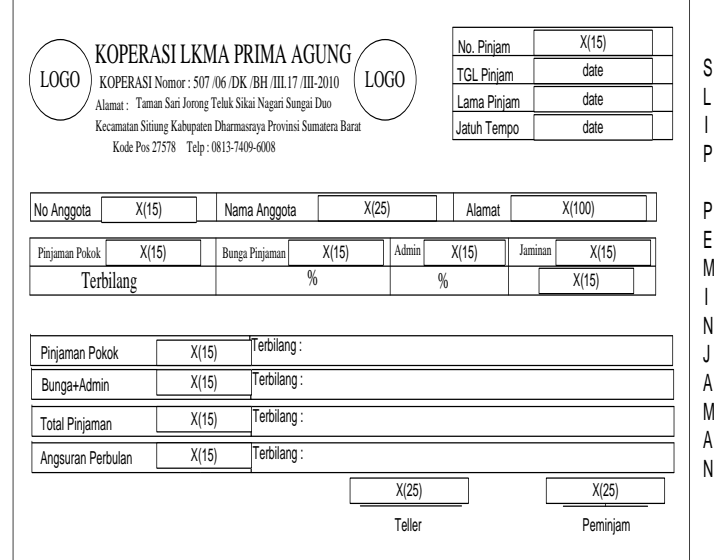

Gambar 19. Rancangan Slip Pinjaman 


\section{i. Rancangan Slip Angsuran}

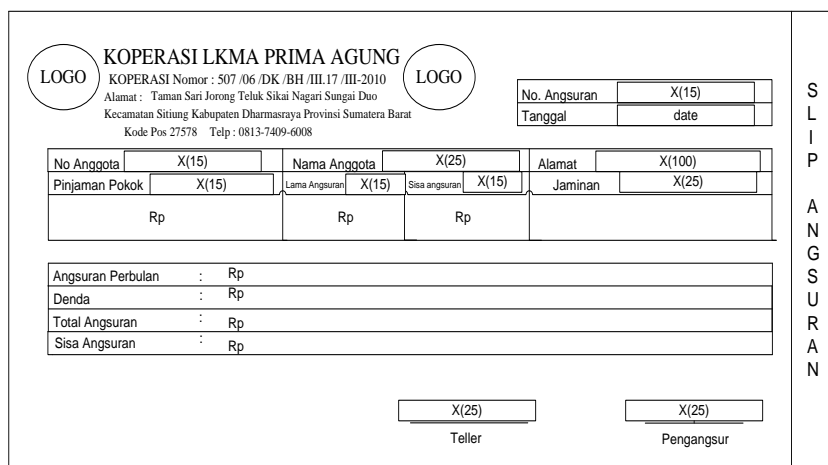

Gambar 20. Rancangan Slip Angsuran

\subsection{Perbandingan Sistem}

Setelah dilakukan penelitian dan pengamatan pada LKMA Prima Agung Kanagarian Sungai Duo Kecamatan Sitiung Kabupaten Dharmasraya mengenai pengolahan data, penulis menemukan beberapa perbedaan dari sistem yang sedang berjalan dengan sistem yang diusulkan sehingga hal ini bisa menjadi perbandingan sistem. Adapun perbandingan sistem yang penulis temukan adalah:

a. Sistem yang sedang berjalan memiliki keunggulan mudah digunakan untuk pengolahan data yang sederhana dan tidak perlu melakukan pelatihan khusus dalam penggunaannya karena hanya menggunakan aplikasi umum yang dipakai di kantor. Namun kelemahannya pada tingkat keakuratan data yang rendah, proses penginputan data pinjaman anggota terpisah dengan perhitungannya, tingkat keamanan data kurang terjamin karena keterbatasan hak akses dan pembuatan laporan hanya dapat dilakukan setelah transaksi selesai dan bukan secara otomatis.

b. Sistem yang diusulkan memiliki keunggulan dalam penyimpanan data karena telah mempunyai database sehingga proses pengolahan data dan keluaran yang dihasilkan lebih cepat dan akurat. Tidak perlu lagi melakukan penginputan data yang terpisah untuk menghasilkan dokumen dan laporan. Begitu juga dalam proses pencarian data yang dapat dipanggil kapan saja diperlukan tanpa harus mencari file terlebih dahulu seperti pada sistem yang sedang berjalan. Sistem yang dilengkapi dengan hak akses juga menjadikan sistem yang diusulkan ini memiliki tingkat keamanan yang lebih terjamin. Adapun kelemahan sistem ini adalah perlunya pelatihan khusus untuk menjalankan program dan harus dilakukan maintenance secara berkala yang membutuhkan banyak biaya.

\section{Kesimpulan}

Setelah melakukan perancangan, penerapan dan pengujian terhadap sistem, maka diperoleh kesimpulan bahwa sistem yang lama memiliki kelemahan seperti ketidak akuratan data karena pengolahannya yang masih konvensional menggunakan buku besar, bisa terjadinya redudansi dan kehilangan data karena tidak ada database dan backup data. Sedangkan dengan menggunakan sistem yang diusulkan ini memberikan kemudahan bagi petugas dalam melakukan pengolahan dan penyimpanan data simpan pinjam dan data anggota LKMA Prima Agung karena telah menggunakan database. Serta keamanan data dapat terjamin karena adanya hak akses.

\section{Ucapan Terimaksih}

Terima kasih atas dukungan dana penelitian dari STMIK Indonesia Padang sesuai dengan Surat Perjanjian Kontrak Penelitian Nomor: 895.002/A.12/STMIK-1/2016

\section{Daftar Pustaka}

[1] H. R. Atikah and Sukadi, "Sistem Informasi Simpan Pinjam pada Koperasi Wanita Putri Harapan Desa Jatigunung Kecamatan Tulakan," Indones. J. Netw. Secur., vol. 2, no. 4, 
2013.

[2] D. Anggoro, M. D. Umar, E. Vinanty, and D. Dananjaya, "Rancangan Sistem Informasi Koperasi Simpan Pinjam Guru dan Pegawai pada Koperasi SMK Manggala Tangerang," Seminar Nasional Teknologi Informasi dan Komunikasi, 2015.

[3] M. Subhan, Analisis Perancangan Sistem. Jakarta: Lentera IImu Cendekia, 2012.

[4] A. Bahra, Analisis dan Desain Sistem Informasi. Yogyakarta: Graha Ilmu, 2005.

[5] Kusrini, Strategi Perancangan dan Pengelolaan Basis Data. Yogyakarta: Andi, 2007.

[6] Jogiyanto, Analisis dan Desain, Yogyakarta: Andi Offset, 2009.

[7] T. Sutabri, Analisa Sistem Informasi, Yogyakarta: Andi Offset, 2012.

[8] Fatansyah, Basis Data. Informatika, Bandung, 2002.

[9] E. Sutanta, Sistem Informasi Manajemen. Yogyakarta: Andi Offset, 2009.

[10] E. Sutanta, Basis Data dalam Tinjauan Konseptual. Yogyakarta: Andi Offset, 2011.

[11] A. Kadir, Dasar Perancangan dan Implementasi Database Relasional, Edisi I. Yogyakarta: Andi Offset, 2009.

[12] A. Kadir, Pengenalan Sistem Informasi Edisi Revisi, Yogyakarta: Andi Offset, 2014. 